\title{
SABÃO ARTESANAL NO ESPAÇO ESCOLAR COMO FERRAMENTA DE SENSIBILIZAÇÃO AMBIENTAL
}

\author{
Marília de Oliveira Lopes ${ }^{1}$ \\ Daniel Sales Pimenta ${ }^{2}$ \\ Bruno Esteves Conde ${ }^{3}$
}

Resumo: Problemas ambientais e suas consequências estão interligados e influenciam todas as esferas do meio biológico e do nosso cotidiano, sendo um dos assuntos mais abordados dentro da disciplina de Biologia em que o uso de novas abordagem na maneira de trabalhar Educação Ambiental é justificável, pois é assunto urgente e necessário devido a degradação ambiental que o planeta vem sofrendo. Muito mais do que ensinar conceitos, é preciso tornar o aluno um participante efetivo e ativo na prática de conservação do meio ambiente. Diante do exposto, o presente estudo avaliou o engajamento de alunos do Ensino Médio, de uma escola pública no interior do estado do Rio de Janeiro, sobre a problemática ambiental, a partir da vivência prática na produção de sabão reciclado de óleo de cozinha usado, em que os alunos foram os protagonistas de cada etapa da sequência didática, inclusive na coleta do óleo, que rendeu uma enorme quantidade de produto arrecadado. A metodologia contou com uma sequência didática desenvolvida no decorrer do ano letivo, contando ainda com palestras, pesquisas, produção de material expositivo e aplicação de questionário. Este último, sendo aplicado antes e após as intervenções, permitindo verificação quantitativa com respostas comparadas através de análise estatística. Foi possível constatar como positiva a participação dos alunos, observando-se uma postura diferenciada destes diante do objeto de estudo, interesse durante palestras de sensibilização e pensamento crítico perante as descobertas dos impactos negativos do homem no ambiente natural, reforçando a potencialidade desse método para aumentar a sensibilização ambiental nos adolescentes, bem como reforçar o propósito da escola de educar para a cidadania. A proposta mostrou-se uma alternativa viável, adaptável ao cronograma escolar e de amplo alcance. Concluindo-se, ainda, que a sequência didática utilizada é passível de ser replicada em outras escolas.

Palavras-chave: Educação Ambiental; Ensino em Biologia; Meio Ambiente; Reciclagem.

1 Universidade de Juiz de Fora. E-mail: lilalopes88@hotmail.com,

Link para o Lattes: http://lattes.cnpq.br/2784091257395437

2 Universidade de Juiz de Fora. E-mail: dasapi48@gmail.com

Link para o Lattes: http://lattes.cnpq.br/1446741795885414

${ }^{3}$ Centro Universitário Estácio de Juiz de Fora. E-mail: bcondebio@hotmail.com

Link para o Lattes: http://lattes.cnpq.br/6874284911392105 
Abstract: Environmental problems and their consequences are interconnected and influence all spheres of the biological environment and of our daily life, being one of the most addressed subjects within the discipline of Biology. The use of new methodologies in the approach to environmental education is justified, as it is an urgent and necessary subject. Much more than teaching concepts, it is necessary to make the student an effective and active participant in the practice of environmental conservation. In view of the above, the present study evaluated the engagement of high school students, from a public school in the interior of the state of Rio de Janeiro, on the environmental issue, based on practical experience in the production of recycled soap from used cooking oil, in which the students were the protagonists of each stage of the didactic sequence, including the collection of oil, which yielded an enormous amount of product collected. The participation of students was positive, observing a different posture from them in relation to the object of study, interest during awareness-raising lectures and critical thinking in face of the discoveries of the negative impacts of man in the natural environment, reinforcing the potential of this method to increase awareness adolescents, as well as reinforcing the school's purpose of educating for citizenship. The proposal proved to be a viable alternative, adaptable to the school timetable and with wide reach. In conclusion, the didactic sequence used can be replicated in other schools.

Keywords: Environmental Education; Teaching in Biology; Environment; Recycling.

\section{Introdução}

O meio ambiente vem sofrendo nas últimas décadas uma devastação sem precedentes, em que os níveis de degradação experimentados por diferentes setores da sociedade têm chamado a atenção de diversos grupos sociais e assumido um papel central nas reflexões, propostas e tomadas de decisões relacionadas à problemática ambiental (SILVA; CARVALHO, 2012).

Segundo Krüger (2001), a sociedade tecnológica fez com que o homem perdesse o domínio sobre os avanços tecnológicos e que o manejo de grandes volumes de materiais alimentícios está diretamente relacionado à geração de detritos e poluentes, à degradação do meio e a outros fatores. Assim sendo, todas as ações que têm a possibilidade de reverter os impactos derivados destes processos são fundamentais para o desenvolvimento sustentável do planeta (BAPTISTA, 2010, p. 8-14).

Para solucionar problemas ambientais, há que se buscar alternativas tecnológicas e gerenciais de controle e prevenção da poluição como, por exemplo, a reciclagem de óleo (FILHO et al., 2013, p. 3026-3035). Além das alternativas supracitadas em grande escala, ações de menor dimensão que possam sensibilizar e conscientizar indivíduos são fundamentais para combater os problemas ambientais, e, neste contexto, justifica-se a importância de práticas, sobretudo, nas escolas, onde o ambiente é propício para desenvolver 
projetos e ações que promovam a aprendizagem, o conhecimento e a mudança de comportamento, muitas vezes com baixo custo e amplo alcance (MENEZES, 2019, p.21).

No ambiente escolar, quando os alunos se deparam com situações que se aproximam de sua realidade, podem assimilar a matéria trabalhada pelos professores em sala de aula, àquilo que estão vivenciando, dessa forma estarão utilizando os conhecimentos adquiridos na sua prática diária e construindo suas próprias ideias por meio do processo de ensinoaprendizagem; assim fazem uma relação do conteúdo com o que já "sabiam", mas ainda não colocavam em prática (COSTA et. al., 2015).

Conforme dados da Pesquisa Nacional de Saneamento Básico (PNSB/IBGE, 2000), a coleta de resíduos sólidos residenciais e comerciais situa-se $94,44 \%$ em área urbana, dos quais $78 \%$ são caracterizados como domésticos: restos de alimentos, produtos de higiene pessoal, óleo de cozinha, embalagens, entre outros (SCHWANTZ et al., 2019, p. 39-55).

Neste contexto há a problemática do óleo de cozinha, que se destaca pelo descarte incorreto (DE LUCENA et al., 2014, p. 08-14). Sabe-se que nos corpos hídricos, por exemplo, o óleo tende a formar filmes oleosos na superfície da água, dificultando a troca de gases com a atmosfera, algo que causa a depleção das concentrações de oxigênio e resulta na morte de peixes e outros organismos, gerando modificação de $\mathrm{pH}$ e depreciando a qualidade da água para vários fins (REIS et al., 2007, p. 1-5).

Buscando agir sobre a problemática do óleo, esta pesquisa propôs a estudantes do Ensino Médio um conjunto de atividades que têm como eixo central a produção de sabão artesanal, a partir do óleo usado, percebido como ferramenta de Educação Ambiental (EA) efetiva de sensibilização acerca dos impactos negativos causados pelo descarte desse resíduo no meio ambiente; o reaproveitamento desse material contribui, dessa forma, para a construção de uma aprendizagem significativa e inserida no cotidiano dos estudantes (DEMOLAY; SANTOS, 2018, p. 1-20)

\section{Breve Histórico da Educação Ambiental no Brasil}

A EA, cada vez mais, tem sua identidade relacionada a formas equilibradas de ser e estar nesse mundo, sendo ferramenta fundamental para a construção de uma consciência planetária, com isso, para que ocorra uma contextualização atual da Educação Ambiental brasileira, faz-se necessário compreender parte do seu desenvolver histórico em que temos: a criação, no Poder Executivo, da Secretaria Especial do Meio Ambiente (SEMA), vinculada ao Ministério do Interior (BRASIL, 2005) em 1973, o estabelecimento da EA em todos os níveis de ensino, inclusive da comunidade pelo Programa das Nações Unidas para o Meio Ambiente PNMA em 1981, perspectiva reforçada pela Constituição Federal em 1988: 
Art. 225: Todos têm direito ao meio ambiente ecologicamente equilibrado, bem de uso comum do povo e essencial à sadia qualidade de vida, impondo-se ao poder público e à coletividade o dever de defendê-lo e preservá-lo para as presentes e futuras gerações.

$\S 1$ Para assegurar a efetividade desse direito, incumbe ao poder público:

[...] VI - a necessidade de "promover a Educação Ambiental em todos os níveis de ensino e a conscientização pública para a preservação do meio ambiente (BRASIL, 1988)

Soma-se a isso, a realização da Conferência das Nações Unidas sobre - Meio Ambiente e Desenvolvimento, conhecida como Rio-92, que teve como resultado a Agenda 21 - apontando o Ministério do Meio Ambiente como um instrumento de planejamento para a construção de sociedades sustentáveis, em diferentes bases geográficas, que concilia métodos de proteção ambiental, justiça social e eficiência econômica (BRASIL, 2012); a instituição da EA como tema transversal pela Lei de Diretrizes e Bases da Educação (LDB) em 1996, que influencia diretamente na instituição da PNMA em 1999.

Legislações posteriores serviram principalmente para regulamentar algumas políticas já implantadas, a exemplo da PNEA, que foi regulamentada em 2002, pelo Decreto no 4.281, de 25 de junho de 2002. Atualmente as atividades de EA em território nacional seguem as diretrizes do ProNEA, sob responsabilidade do MMA, tendo em vista que mesmo homologada em 2017, a Base Nacional Curricular Comum (BNCC), que é um dos documentos mais recentes na área de educação ainda não aborda o assunto de forma definitiva (BRASIL, 2017). Por sua transversalidade, a EA não possui um currículo específico, mas há diversas publicações para seu desenvolvimento em escolas elaboradas pela parceria entre o MMA e o MEC.

\section{Perspectivas da Educação Ambiental para o Ensino}

Segundo o Art. $2^{\circ}$ da PNEA, a EA é um componente essencial e permanente da educação nacional, em caráter formal, é aplicada por instituições de Educação Básica (públicas e privadas), devendo ser desenvolvida de forma contínua e permanente, em todos os níveis e modalidades, construindo valores ecológicos no âmbito disciplinar e interdisciplinar (TALAMONI et al., 2018, p. 68).

As Diretrizes Curriculares Nacionais para o Ensino Médio mencionam a sustentabilidade ambiental como meta universal entre os pressupostos e fundamentos para um Ensino Médio de qualidade social (BRASIL, 2012).

Segundo Novicki e Souza (2010), a EA está inserida nos espaços de ensino, porém, ainda não há parâmetros bem definidos que perpassem sua obrigatoriedade e possibilitem sua implantação efetiva. 
As potencialidades da EA ainda são pouco aproveitadas nas escolas e é imprescindível sua implementação como estratégia dirigida para promover a sensibilização e conscientização socioambiental. Integrar as reflexões atuais sobre os impactos ambientais é fundamental ao processo de aprendizagem e para a construção de significados; a escola atual, portanto, não pode ignorar as questões ambientais que estão presentes no cotidiano de cada aluno (VIRGENS, 2011).

A EA implica uma nova concepção do papel da própria escola. A articulação de seus conceitos, métodos, estratégias e objetivos é complexa e ambiciosa, tendo dimensões ecológicas, históricas, culturais, sociais, políticas e econômicas da realidade e da construção de uma sociedade baseada em princípios éticos e de solidariedade (COLESANTI, 1996, p. 35).

\section{Relevância e Justificativa do Estudo}

Nota-se que grande esforço tem sido despendido na busca de alternativas de reutilização de resíduos oriundos de atividades humanas e diversas pesquisas têm demonstrado o emprego destes rejeitos na produção de biodiesel e também de sabão (SCHWANTZ et al., 2019, p. 39-55).

Deste modo, é possível dar um destino viável ao óleo, do ponto de vista ambiental e econômico, com uma produção de reciclagem simples que traz benefícios para a escola e possibilita ao estudante compreender os conteúdos de Biologia, vinculados às interferências humanas no meio, de forma mais significativa (VIZÚ et al., 2018, p 05).

De acordo com a Política Nacional de Educação Ambiental (PNEA):

Art. $1^{\circ}$ - Entende-se por Educação Ambiental os processos por meio dos quais o indivíduo e a coletividade constroem valores sociais, conhecimentos, habilidades, atitudes e competências voltadas para a conservação do meio ambiente, bem de uso comum do povo, essencial à sadia qualidade de vida e sua sustentabilidade (BRASIL, 1999).

A PNEA também estabelece a EA como componente essencial e permanente da educação nacional, que deve estar presente, de forma articulada, em todos os níveis e modalidades do processo educativo, incumbindo, dentre outras organizações, as instituições educativas de promover EA de maneira integrada aos programas educacionais que desenvolvem, gerando um pluralismo no que diz respeito às estratégias, de modo a garantir maiores oportunidades para a construção do conhecimento (VIVEIRO; DINIZ, 2009, p. 1-12).

A escola ainda é considerada como a fonte de transmissores do conhecimento e os membros do ambiente escolar (alunos, professores e funcionários) são multiplicadores de ações que visam capacitar seres humanos 
preparados para alterar o cenário atual reduzindo os problemas em relação ao descarte incorreto de resíduos oleosos residenciais e, consequentemente, minimizando os impactos ambientais (SCHWANTZ et al., 2019).

Portanto, atividades que visam produzir sabão artesanal a partir do óleo de cozinha usado com estudantes são úteis em várias vertentes, pois desenvolvem diretamente princípios de EA como a concepção do meio ambiente em sua totalidade, a dependência entre os meios natural, socioeconômico e cultural, sob o enfoque da sustentabilidade, e a abordagem articulada das questões ambientais locais, regionais, nacionais e globais (BRASIL, 1999).

Além de ser uma alternativa simples, permite que o professor seja capaz de ajudar seus alunos a relacionar a prática com a teoria, contribuindo assim para a formação de jovens conscientes e capazes de repensar suas atitudes em relação ao meio ambiente (SILVA, 2019). O tom dessas afirmações revela uma ideia de pedagogia em que a sensibilidade para a percepção dos problemas ambientais está muito presente, privilegiando a dimensão subjetiva do processo educativo (TOZONI-REIS, 2008).

\section{Desenvolvimento das atividades}

Seguindo as legislações vigentes, o projeto foi inserido transversalmente e de forma concomitante aos conteúdos da disciplina de Biologia, portanto sem interferência na grade curricular, aplicado ao longo do semestre sendo aliado ao objetivo de formação do aluno enquanto cidadão. Com atividades desenvolvidas e norteadas pelos princípios e objetivos da EA estabelecidos pela PNEA, tendo por base a produção de sabão no espaço escolar como ferramenta de sensibilização ambiental.

O saber ambiental não nasce de uma reorganização sistêmica dos conhecimentos atuais. Este se gera através da transformação de um conjunto de paradigmas do conhecimento e de formações ideológicas, a partir de uma problemática social que os questiona e os ultrapassa (LEFF, 2001, p. 208).

Para alcançar os objetivos propostos foram desenvolvidas atividades, a fim de não só compartilhar com os estudantes os métodos de produção de sabão artesanal, mas também de criar e reforçar valores socioambientais por meio de seu envolvimento em ações que permitam esta criticidade.

Para tanto este estudo foi aprovado pelo Comitê de Ética em Pesquisa com Humanos, teve autorização da instituição de ensino em que foi aplicado, assim como o consentimento necessário de todos os participantes e seus responsáveis. O engajamento de alunos do Ensino Médio sobre a problemática ambiental foi avaliado a partir da vivência prática na produção de sabão reciclado bem como avaliação quantitativa por meio de questionário.

A implementação das atividades desta pesquisa foi realizada no Colégio Estadual Padre Sebastião da Silva Pereira, localizado nas proximidades da 
região central do município de Valença/RJ, envolvendo seis turmas de Ensino Médio, durante as aulas da disciplina de Biologia, sob regência da professora autora deste escopo. Totalizando 123 estudantes, com faixa etária média entre 15 e 18 anos, no período do segundo semestre de 2019.

As etapas das atividades incluíram: aplicação de dois questionários, pesquisa extraclasse, elaboração de cartazes, folders e materiais educativos sobre conscientização ambiental, mobilização e apresentação do projeto aos estudantes, palestras com temática ambiental, gincana de coleta de óleo de cozinha usado e oficina de produção de sabão artesanal utilizando parte do resíduo coletado.

Conforme as etapas supracitadas, um questionário contendo 13 questões $(Q)$, compostas de uma linguagem simples e apropriada, conduzido de forma estruturada, com perguntas diretas e fechadas; e semiestruturada, com perguntas abertas. Aplicado aos estudantes no início e outro ao final do projeto. As perguntas foram respondidas de forma individual, aplicadas em cada turma separadamente, em horário regular de aula.

Para montagem das perguntas contidas no questionário alguns critérios de categorização foram seguidos (Quadro 1).

Quadro 1 - Critérios de montagem do Questionário

\begin{tabular}{|c|c|}
\hline Categoria & Critério de Análise \\
\hline $\begin{array}{l}\text { Interesse e ações } \\
\text { socioambientais }\end{array}$ & $\begin{array}{l}\text { Q1) Você se interessa por assuntos relacionados ao meio ambiente? } \\
\text { Q2) Você toma alguma atitude em seu dia a dia para ajudar o meio } \\
\text { ambiente? }\end{array}$ \\
\hline $\begin{array}{l}\text { Reutilização de } \\
\text { produtos }\end{array}$ & $\begin{array}{l}\text { Q3) Você já ouviu falar em reutilização de produtos? } \\
\text { Q4) Antes de jogar algo fora, você pensa em como poderia reutilizá-lo? }\end{array}$ \\
\hline $\begin{array}{l}\text { Descarte, efeitos } \\
\text { prejudiciais, } \\
\text { consumo e } \\
\text { reaproveitamento } \\
\text { do óleo de cozinha }\end{array}$ & $\begin{array}{l}\text { Q5) Como é descartado o óleo de cozinha depois de usado em sua } \\
\text { casa? } \\
\text { Q6) Você conhece algum ponto de coleta de óleo usado em seu bairro? } \\
\text { Q7) Você conhece os efeitos prejudiciais do descarte indevido do óleo de } \\
\text { cozinha no meio ambiente? } \\
\text { Q8) Você conhece os efeitos prejudiciais do óleo de cozinha nos corpos } \\
\text { dos organismos vivos? } \\
\text { Q9) Você sabe qual a quantidade média de óleo usado em sua casa todo } \\
\text { mês? } \\
\text { Q10) Você conhece algum projeto que trate da destinação do óleo } \\
\text { utilizado na cozinha? } \\
\text { Q11) Já teve contato ou ouviu falar de sabão feito com óleo de cozinha? }\end{array}$ \\
\hline $\begin{array}{l}\text { Plantas aromáticas } \\
\text { e plantas } \\
\text { medicinais }\end{array}$ & $\begin{array}{l}\text { Q12) Conhece os benefícios das plantas aromáticas associadas ao } \\
\text { sabão? } \\
\text { Q13) á ouviu falar em plantas medicinais? }\end{array}$ \\
\hline
\end{tabular}
Fonte: Elaborada pela autora.

$\mathrm{Na}$ segunda etapa uma série de pesquisas extraclasse foi sugerida, com temáticas que abordavam questões como: interferências humanas negativas sobre a natureza (solo, água e atmosfera), a diferença entre reciclagem e reutilização, características, tipos e consequências de atividades antrópicas, o 
processo de saponificação, incluindo-se aqui a questão do óleo usado e seu descarte incorreto e reciclagem, além do possível uso de plantas aromáticas para agregar valor a produtos como o sabão.

Houve também neste mesmo período uma primeira palestra para fins de sensibilização dos alunos com relação ao cuidado com meio ambiente, abordando a importância do papel da comunidade e de ações locais para mitigar os impactos negativos que a natureza vem sofrendo.

Em etapa subsequente, os alunos construíram um folder educativo baseado nas pesquisas extraclasse, para eventual distribuição e seguidamente foi realizada uma gincana de coleta de óleo, em que os alunos foram incentivados a coletar e trazer para a escola o óleo usado recolhido em suas próprias casas ou ainda em outros locais da cidade.

Houve ainda nova palestra, agora com o professor Daniel Sales Pimenta, associado da Universidade Federal de Juiz de Fora, em que ele, com sua ampla experiência em produtos naturais, etnobotânica, produção de plantas medicinais e fitoterapia, falou aos alunos acerca da conscientização sobre a preservação do meio ambiente, mostrando a interdependência entre o homem e o meio que nos cerca. A palestra também discorreu sobre o uso de produtos oriundos do ambiente natural para benefício humano, como as plantas medicinais, sua importância, meios adequados do uso e potencialidades, trazendo luz à necessidade de uma relação mais amistosa com a natureza a fim de evitar consequências negativas a médio e longo prazo.

O período de coleta pela gincana transcorreu durante o semestre e ao final deste, fazendo o uso de parte do óleo coletado pelos estudantes na gincana supracitada, os alunos tiveram a oportunidade de participar da oficina prática de fabricação de sabão artesanal.

A prática de saponificação foi feita com cada turma em seu horário próprio da aula de Biologia, em que estudantes foram divididos em grupos de 5 a 6 integrantes para os quais foi entregue um passo a passo a ser seguido, bem como os ingredientes básicos para efetuar a atividade, materiais esses listados abaixo:

- $500 \mathrm{ml}$ de óleo de cozinha usado e coado;

- $70 \mathrm{ml}$ de água;

- $65 \mathrm{~g}$ de soda cáustica em escamas;

- $7 \mathrm{ml}$ de álcool.

- Recipientes para o molde do sabão caseiro (formas);

- 1 colher de pau;

- 1 balde grande;

- 1 recipiente pequeno.

O uso de equipamentos de proteção individual (EPIs) fez-se necessário, e o papel do professor como mediador da prática foi reforçado pela ênfase em descrever que o manuseio da soda cáustica deve ser feito com cuidado. 
Após esta etapa, os alunos responderam novamente a um questionário, com as mesmas perguntas usadas no questionário do início das intervenções a fim de avaliar a conscientização e os conhecimentos adquiridos sobre temas relacionados ao meio ambiente. Os dados foram tabulados e as análise descritiva dos dados obtidos, a partir das quais foram produzidas tabelas e gráficos de modo a facilitar a observação, Esta última etapa seguiu os mesmos procedimentos da primeira aplicação, sendo que o número de alunos que respondeu foi 103, na primeira etapa 123 alunos responderam.

\section{Resultados e Discussão}

A sequência didática aplicada buscou sensibilizar os alunos com ampliação do domínio de um conteúdo feita de forma gradual, assim como ressalta Lima (2018), para o autor, ao organizar uma sequência didática, o professor planeja as etapas explorando diversos conteúdos procedimentais.

Na primeira etapa a aplicação do questionário se fez importante, pois permitiu avaliar os conhecimentos prévios dos alunos sobre a temática. Marconi e Lakatos (2003) destacam a importância de questionários assim, afinal eles atuam como um instrumento de coleta de dados e permitem ao professor entender o ponto de vista dos educandos, para, a partir disso, traçar as estratégias de modo a desenvolver uma atividade significativa para o aluno.

Conforme citado anteriormente optou-se pelo uso de pesquisas extraclasse para que os alunos pudessem aprofundar seu conhecimento em temas ligados ao projeto e vinculados à Biologia. Como exemplificado por Santos (2017) o professor tem papel importante ao motivar e nortear os alunos nas técnicas de pesquisa extraclasse e na busca por referenciais teóricos de forma que o aluno obtenha conhecimentos. Assim, esta etapa foi conduzida de modo a orientar e a acompanhar todo o processo de investigação, visando conscientização e reflexão dos estudantes.

Ocorreu a elaboração de cartazes, expressando alguns conhecimentos adquiridos na forma de desenhos e resumos (Figura 1),

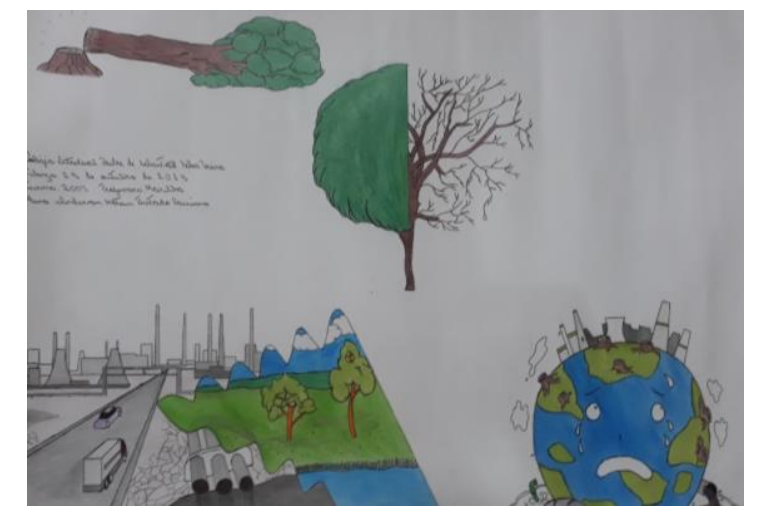

Figura 1: Cartaz sobre conscientização ambiental elaborado por alunos.

Fonte: Registro fotográfico da autora, 2019. 
O amadurecimento demonstrado nos diálogos após as pesquisas que transcorreram deixou evidente e mostrou o crescente interesse dos alunos por assuntos como reciclagem e reutilização: muitos foram os relatos de que antes não sabiam identificar a diferença entre tais termos e pode-se perceber a disposição dos alunos em produzir materiais por conta própria a fim de facilitar o entendimento de outras pessoas.

Alguns optaram por fazer cartazes, outros por apresentação em Power Point e outros ainda pela construção de objetos com possibilidade de reutilização, conforme Bzuneck e Guimarães (2010), que, fazem relação entre ato de escolha e autonomia como gerador de envolvimento pessoal, baixa pressão e alta flexibilidade e, até mesmo, uma liberdade psicológica. A autonomia dos estudantes foi levada em consideração e a autora sempre esteve como agente mediador, fato indispensável para a construção do conhecimento, reforçado por Costa (2019) que traz o professor como aquele que coordena as atividades em torno de algum problema e não mais aquele que transmite determinado saber pronto.

Ainda buscando diversificar as atividades, o uso complementar de palestras proporcionou melhor entendimento do cuidado com nosso ambiente local. As palestras voltadas para a EA são apontadas como ações interdisciplinares que visam, por meio de debates, despertar a visão holística do meio ambiente e a interdependência homem e natureza (SILVA, 2020). Assim, buscou-se instigar o pensar sobre os cuidados com o meio ambiente.

A etapa intitulada gincana de coleta, constou de uma arrecadação voluntária de óleo de cozinha usado, sendo este um produto que, como assinalado por $\mathrm{Da}$ Cruz (2019) é resultante de processos de fritura que modificam suas características, inviabilizando o consumido, necessitando assim que seja descartado. Segundo pesquisa da empresa Bunge (2009) muitos brasileiros consomem, em média, mais de 20 litros do produto por ano, fazendo-se necessário, portanto, sua coleta de modo adequado para que o produto não cause danos principalmente os cursos d'água, em que 1 litro de óleo pode contaminar até 25 mil litros de água (SABESP, 2011).

$O$ voluntariado e o engajamento permitiram avaliar se as atividades até então aplicadas haviam surtido efeito, fato prontamente confirmado com base na empolgação, nos levantamentos, nas buscas e num enorme volume de óleo coletado. Houve um total de 1716 litros arrecadados (Figura 2).

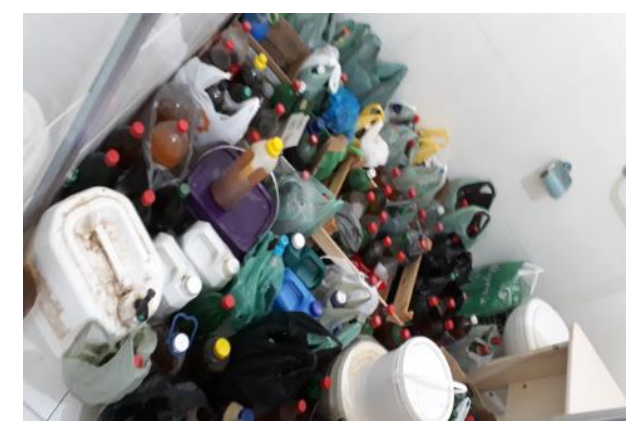

Figura 2 - Óleo arrecadado durante a Gincana. Fonte: Registro fotográfico da autora, 2019. 
Após a aplicação das intervenções supracitadas, a realização da oficina de saponificação proporcionou ao estudante uma vivência prática enriquecedora. Essa constatação também foi relatada por Schwantz (2019), quando em atividade semelhante, percebeu que a prática se comprovou como uma alternativa simples e eficaz de reutilização de óleos de cozinha residuais. A prática permitiu que eles se vissem como sujeitos ativos do processo de ensino aprendizagem, fazendo sua parte localmente para minimizar os impactos desse óleo, que poderia estar contaminando água e solo. É fundamental que o professor promova estratégias que coloquem o aluno como protagonista e como um ser mais autônomo no processo ensino aprendizagem segundo De Castro (2019).

Notadamente os jovens se mostraram animados ao ver que seria usado na oficina de saponificação o óleo que eles próprios coletaram, sendo assim, eles veriam na prática a transformação daquele resíduo; seguindo a conceituação de Loureiro, (2007) em que ele descreve que a questão não é somente conhecer para se ter consciência de algo, mas conhecer inserido no mundo para que se tenha consciência crítica do conjunto de relações que condicionam certas práticas, nesse movimento, superarmos as condições inicialmente configuradas.

A escolha dessa oficina como ferramenta de sensibilização validou positivamente os objetivos propostos, pois, esse tipo de experimento assim como reforça, Carvalho (1999), é ponto de partida para desenvolver a compreensão de conceitos: isso leva o aluno a participar de seu processo de aprendizagem e a sair da postura passiva para começar a agir sobre o seu objeto de estudo, relacionando o objeto com acontecimentos. Ou seja, o discente pôde fazer ligação entre conhecimento, pesquisa e atitude prática.

Ao final do projeto foi feita uma nova aplicação do questionário usado no início da intervenção. De acordo com Godoy (2005), espera-se que o ato de pesquisar não seja entendido somente como uma atividade meramente técnica e objetiva, mas como uma atividade que também englobe as subjetividades do pesquisador e dos estudantes. Neste contexto esta análise dos dados obtidos por meio do questionário busca complementar as percepções adquiridas durante o desenvolvimento das atividades desta pesquisa.

De acordo com Godoy (2005, p. 86) dada a abundância de dados gerados em uma pesquisa qualitativa, é importante a utilização de recursos visuais (como gráficos, modelos, quadros e figuras) que permitam organizá-los e sumariá-los, tornando-os mais acessíveis aos pesquisadores e aos futuros leitores. A partir das justificativas apresentadas, nas representações gráficas divulgadas nos resultados, algumas perguntas que apresentarem validação (significativa) - com base no desvio padrão da amostra - valem discussões a partir de suas observações, considerando as variações entre as respostas da aplicação inicial e final com valores próximos a 12,51\%.

A análise descritiva dos dados obtidos através da aplicação dos 
Excel 2016 MSO versão 16.0.12527.20612, através das fórmulas disponíveis e do suplemento Análise de dados. A partir da amostra populacional obteve-se os seguintes resultados (Tabela 1):

Tabela 1: Análise Estatística Descritiva.

\begin{tabular}{cc}
\hline Medidas & Resultados \\
\hline Respostas obtidas na aplicação inicial & 123 \\
\hline Escore-z da aplicação inicial & 0,71 \\
\hline Respostas obtidas na aplicação Final & 103 \\
\hline Escore-z da aplicação final & $-0,71$ \\
\hline Média de respostas $(\mu)$ & 113 \\
\hline Desvio Padrão Amostral $(\sigma)$ & 14,14 \\
\hline Variância & 200 \\
\hline Coeficiente de variação $(\%)$ & 12,52 \\
\hline Quantidade Média de Respostas & $113 \pm 14,14$ \\
\hline
\end{tabular}

Foi construído, com a utilização do mesmo software citado, gráficos individuais com os resultados da aplicação dos questionários inicial (I) e final (II) a fim de demonstrar uma análise dos dados obtidos com base na frequência relativa das respostas nas questões (Q). Destacam-se agora alguns pontos importantes nas respostas dos questionários e sua aplicação propriamente como sendo de fundamental importância, figurando por si só como uma ferramenta que leva a pensar sobre determinados assuntos.

\section{Representação gráfica das respostas do questionário}

A questão (Q1) não apresentou resultados possíveis de validação estatística devido às variações estarem abaixo do valor estipulado, considerando possíveis desvios. Valendo significância para o fato de as respostas "sim" continuaram maiores quando comparados ao "não" e ao "razoavelmente interessados", mostrando que a inserção foi promissora, havendo mudança de opinião.

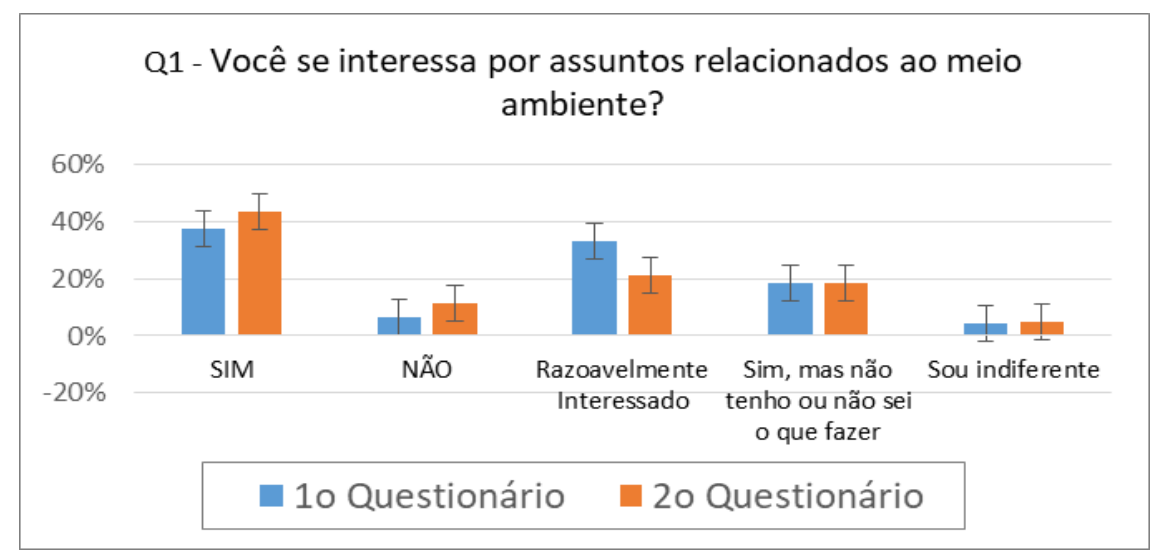

Revbea, São Paulo, v.16, № 1: 450-471, 2021. 
A questão (Q2) apresentou duas variações válidas. Houve um aumento significativo de respostas positivas em relação às atitudes cotidianas em relação a colaboração com o meio ambiente paralelo a diminuição de respostas em que afirmam não tomar nenhuma atitude, mas que gostariam de fazer algo.

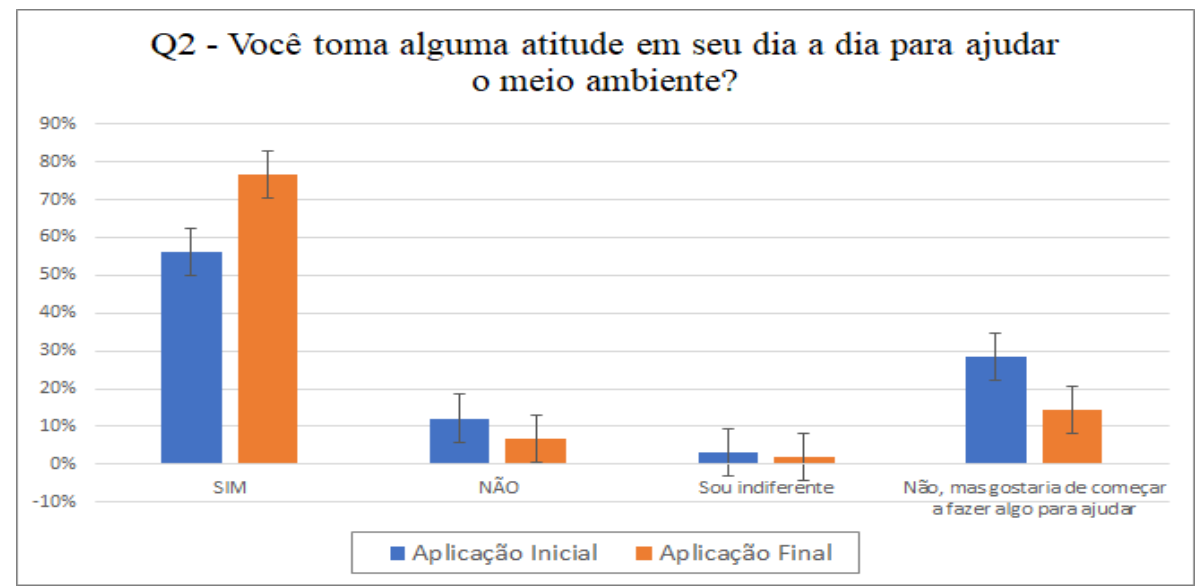

A questão 3 (Q3) não apresentou resultados possíveis de validação em relação a variação, mas notadamente o "sim" se manteve constante e superior às outras questões.

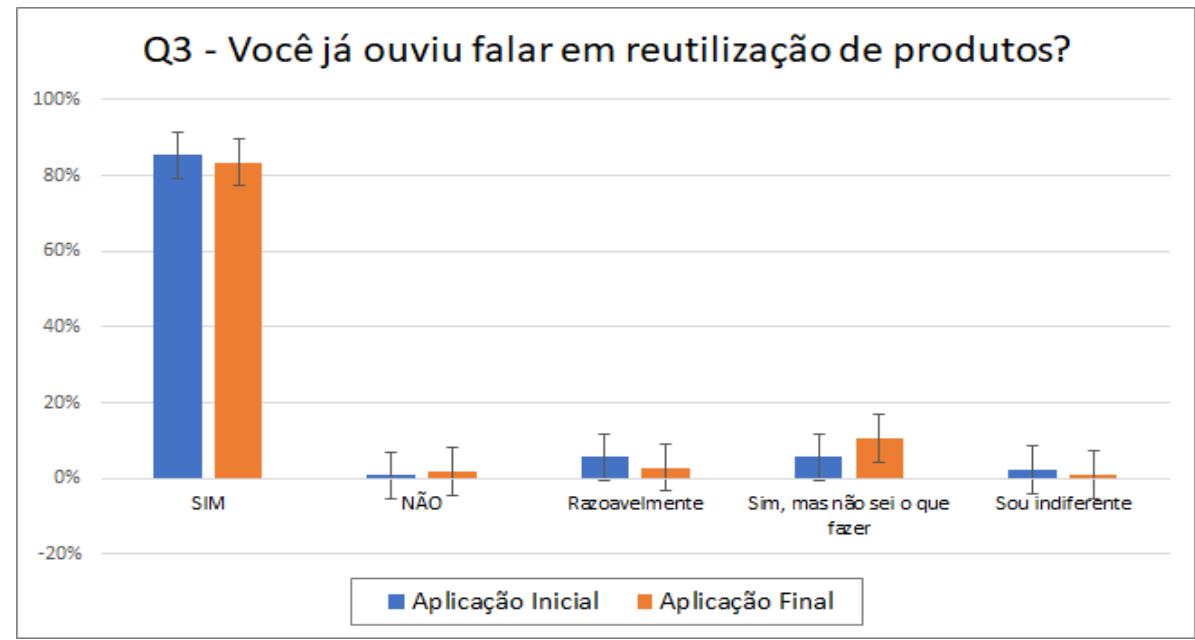

A quarta questão (Q4) também não apresentou resultados possíveis de validação. Entretanto, nota-se que o "não" ainda prevalece mesmo tendo diminuído na segunda aplicação. Mas o "sim" teve aumento, mostrando resultado positivo da inserção. 


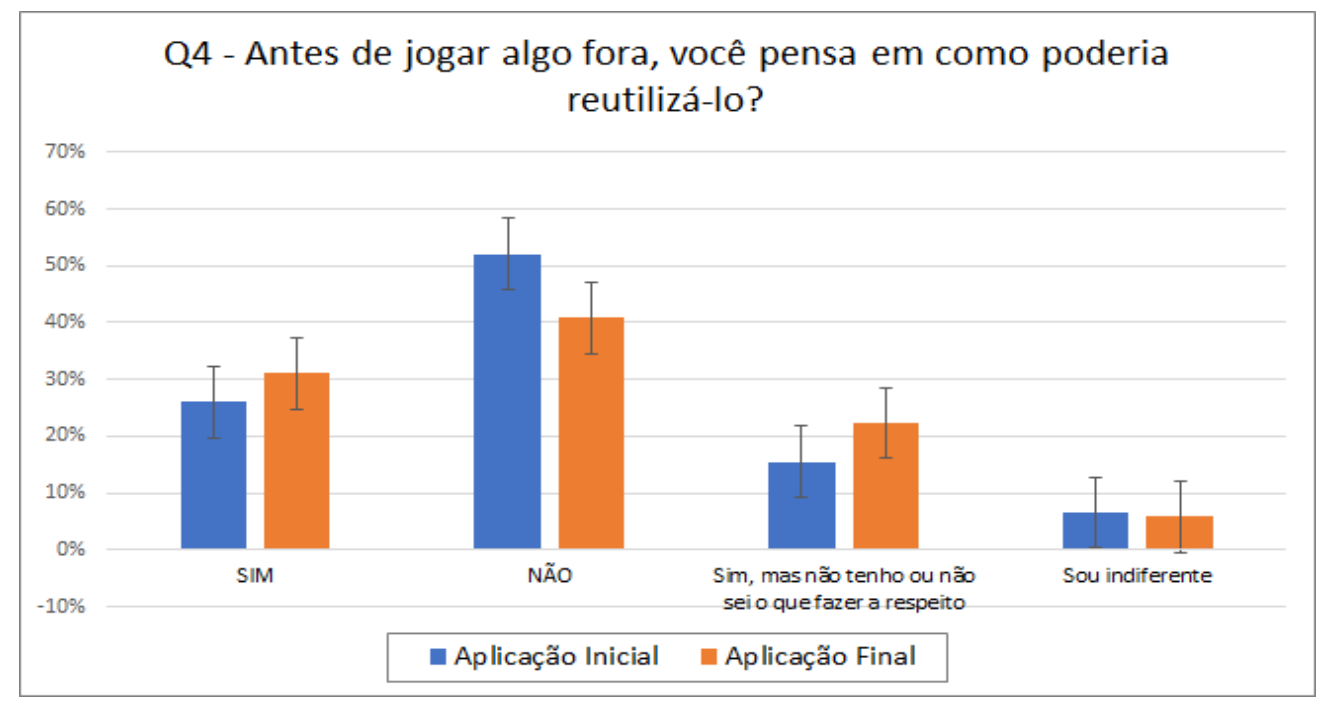

Os resultados obtidos na questão 5 (Q5) apontam aumento para "descarte em ponto de coleta", mostrando crescimento em virtude de o colégio ter ser tornado uma referencia para os alunos.

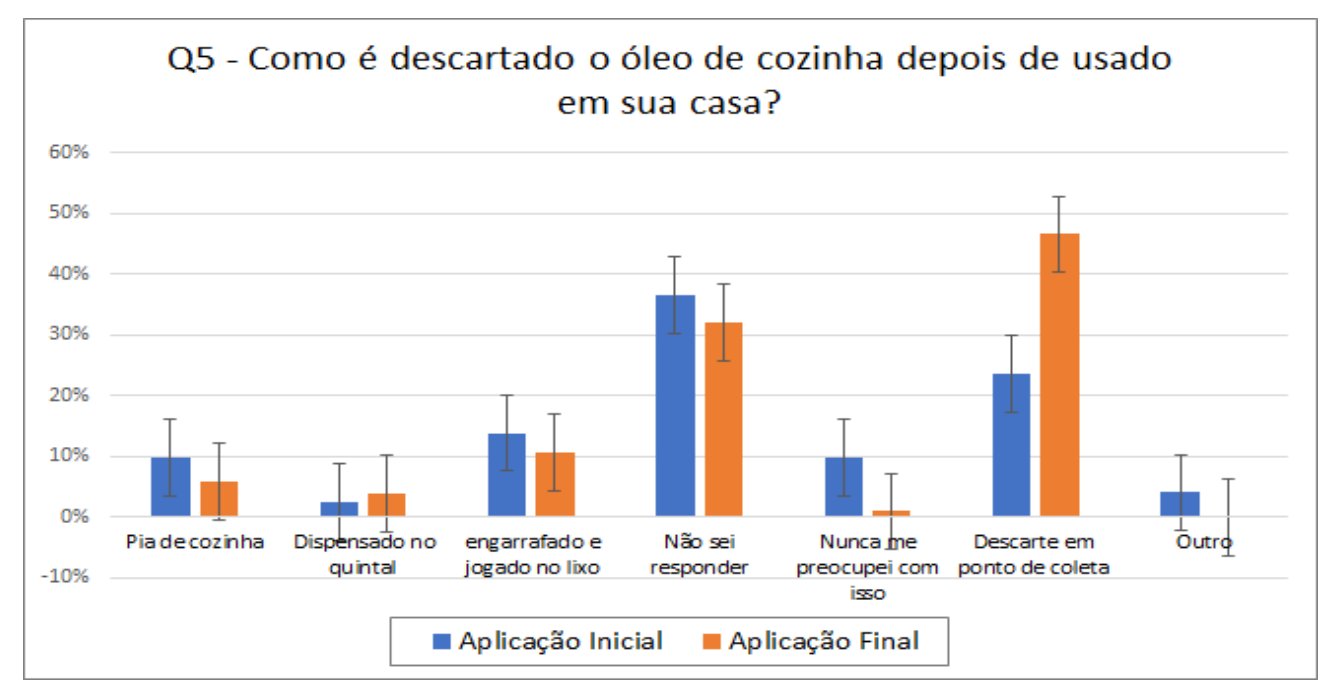

As respostas válidas da sexta questão (Q6) indicam um significativo aumento do "sim" que trata do conhecimento sobre algum ponto de coleta de óleo usado próximo à residência dos participantes. A indiferença de "nunca procurei saber" teve queda significativa na segunda aplicação e é estatisticamente menor do que o "sim" da segunda aplicação. No entanto antes da aplicação do projeto esses pontos provavelmente passavam despercebidos pelos alunos. 


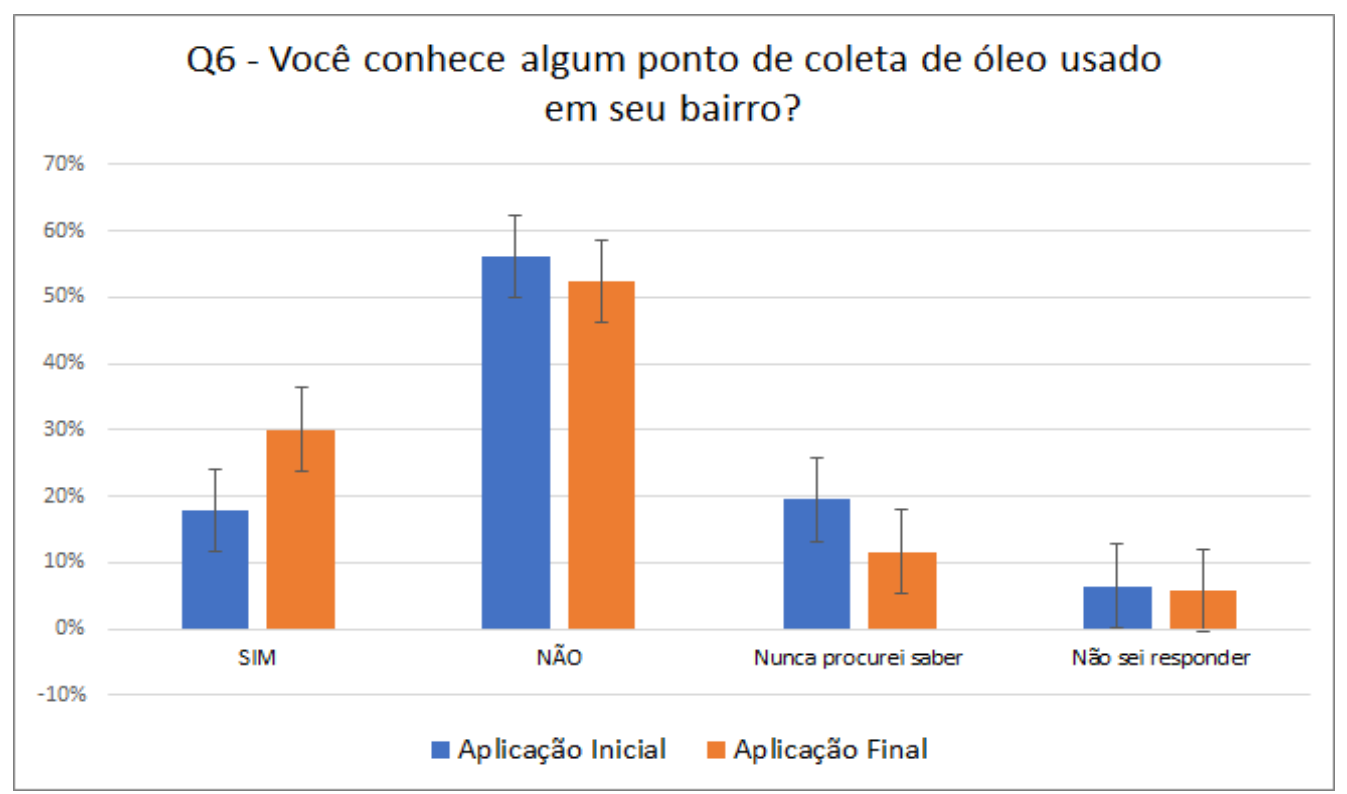

Percebe-se na questão 7 (Q7) que a informação acerca dos efeitos prejudiciais do descarte indevido do óleo de cozinha existia entre os estudantes, mas a inserção provocou um aumento significativo nesse conhecimento.

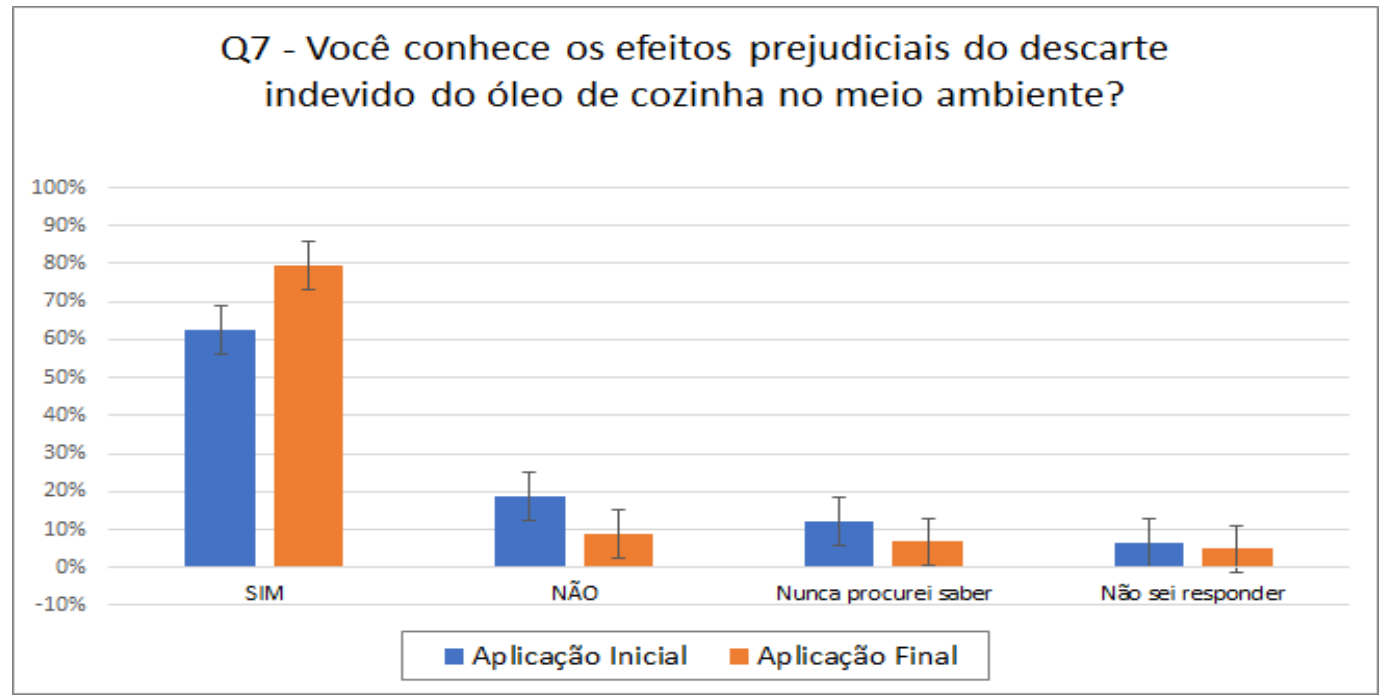

A questão 8 (Q8) não apresentou resultados possíveis de validação dentro dos critérios estatísticos. Porém é possível observar aumento do número de respostas positivas, demonstrando que houve ganho de conhecimento. 


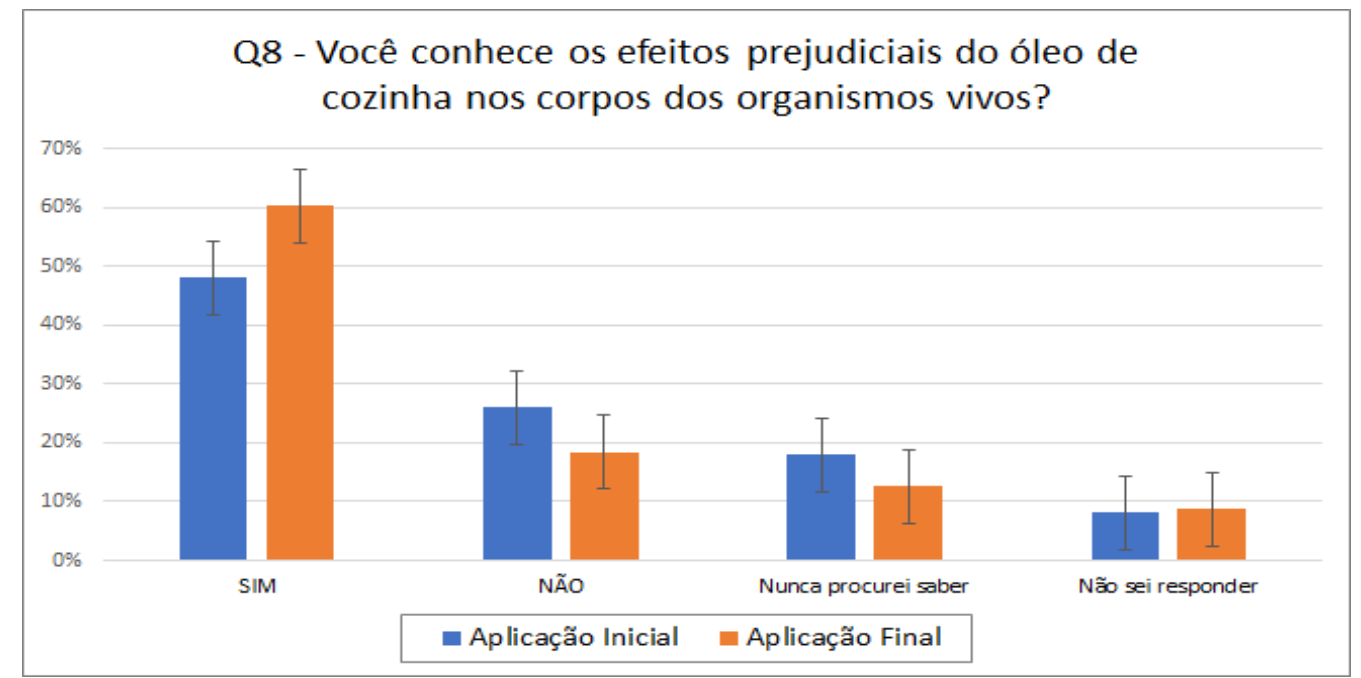

Na questão 9 (Q9) nota-se que parte dos alunos afirmaram não ter um conhecimento sobre a quantidade média de óleo de cozinha utilizado por mês em suas residências.

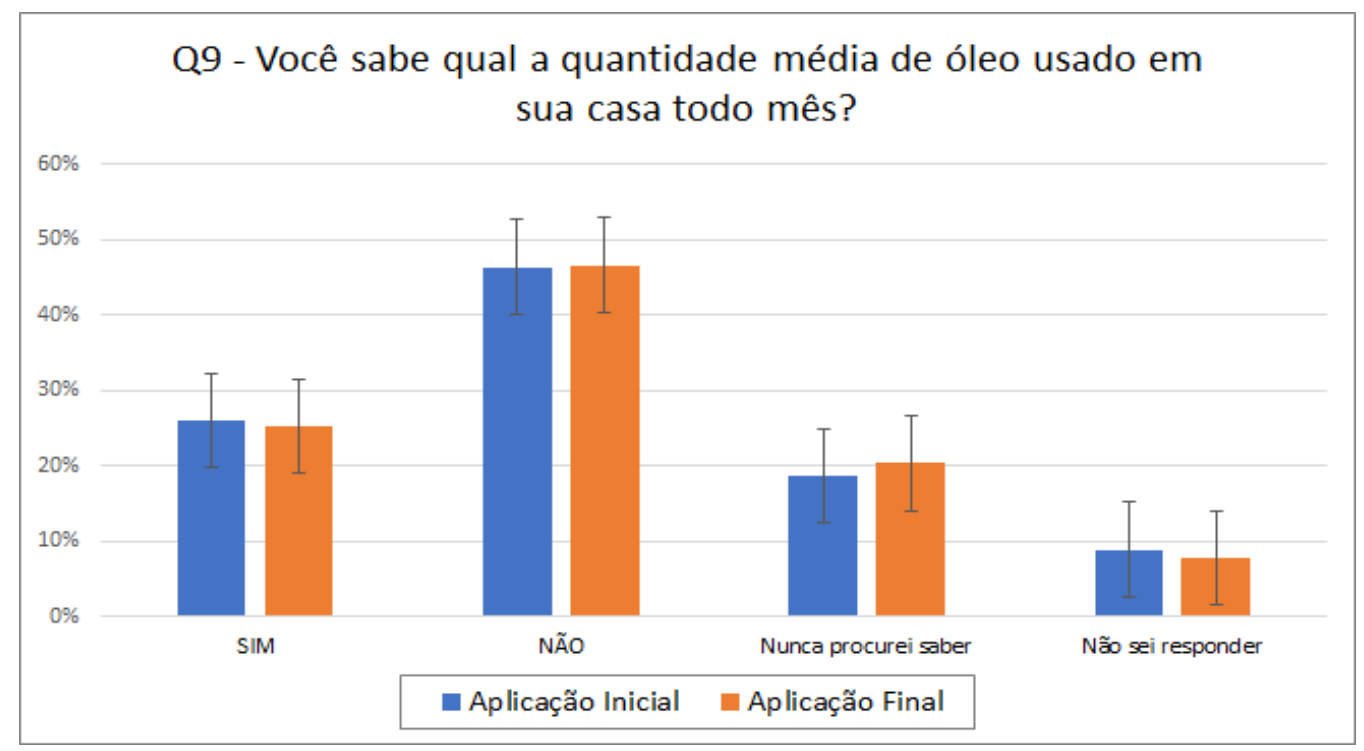

Pelos resultados válidos na questão 10 (Q10) percebe-se que uma grande parte dos alunos não conhecia nenhum projeto para destinação adequada do óleo de cozinha usado, mas as respostas mudaram significativamente após a realização das atividades. 


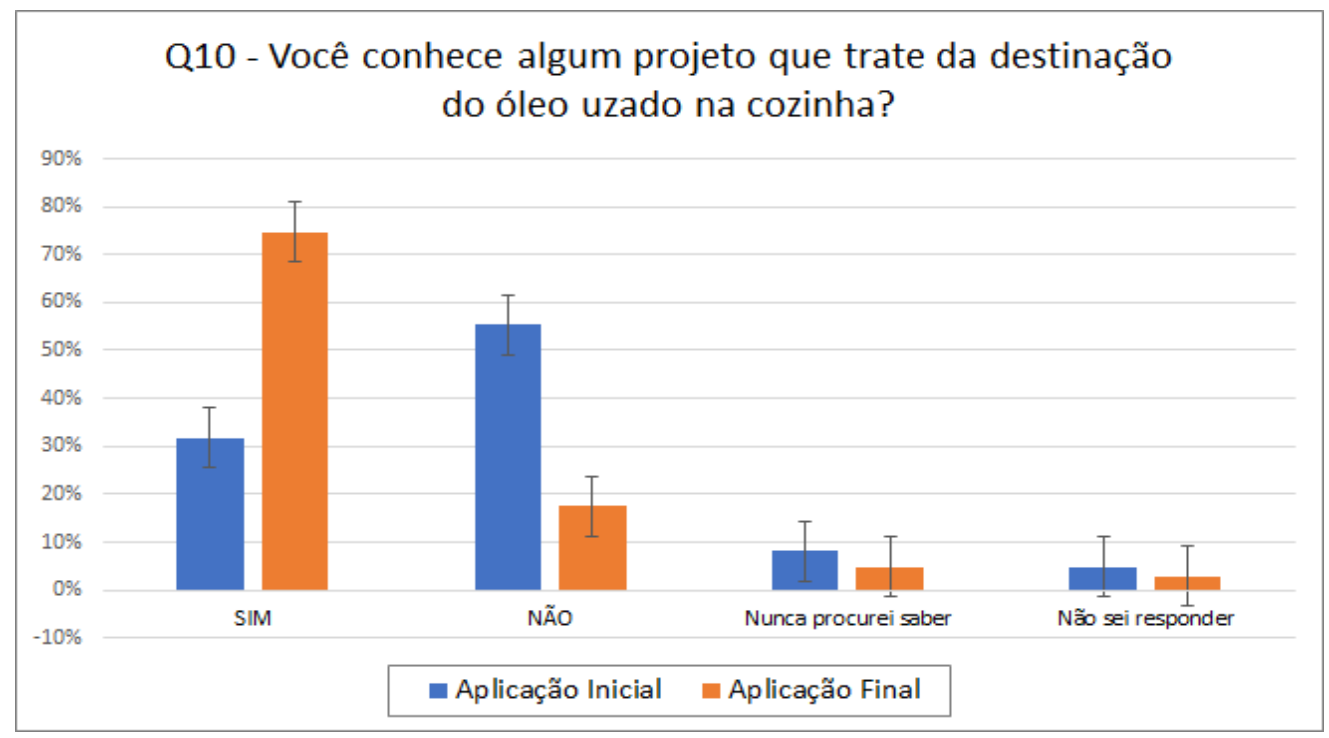

$\mathrm{Na}$ questão 11 (Q11) buscou-se analisar o conhecimento prévio e posterior dos alunos sobre o sabão artesanal feito com óleo de cozinha usado. Sendo significativo o fato de, após a inserção eles terem conhecimento esse tipo de reciclagem. A indiferença passou a ser nenhuma, assim como não ter interesse em saber em contrapartida o "sim" foi praticamente unanime com rendimento em torno de $1 / 5$ de conscientização especificamente na questão da fabricação do sabão.

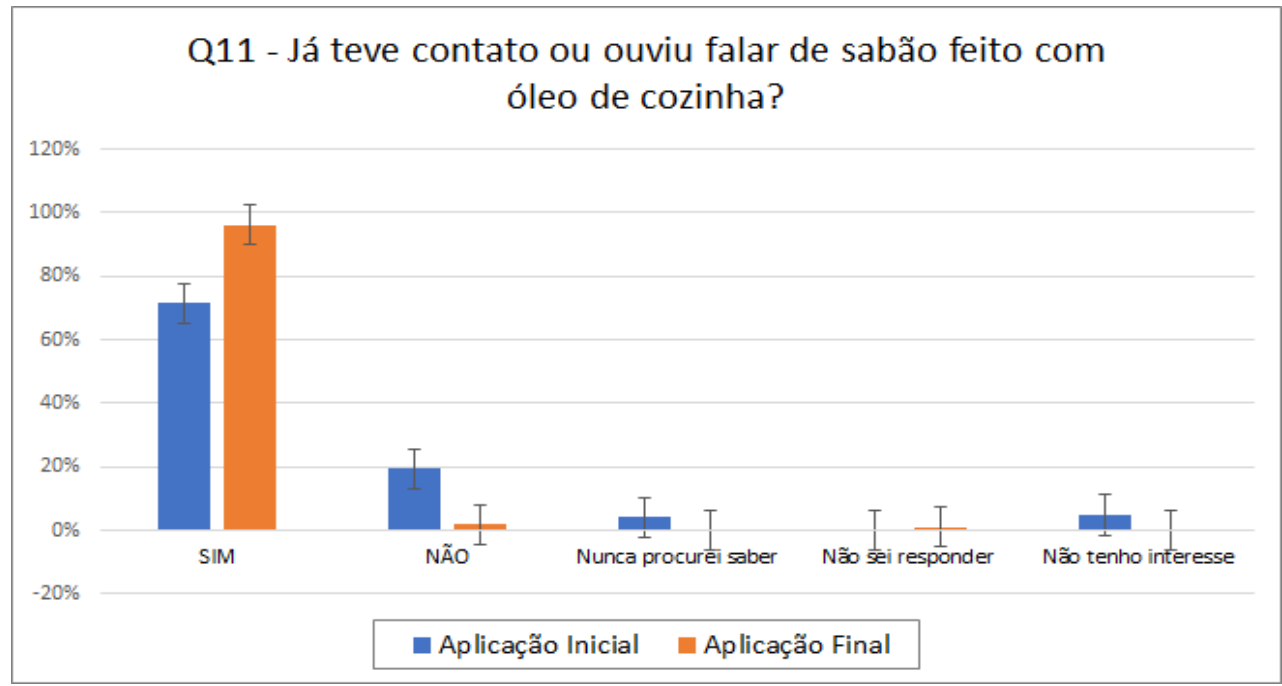

Nota-se que o quantitativo de alunos que responderam a questão 12 (Q12) que nunca procuraram saber sobre os benefícios das plantas aromáticas associadas ao sabão na aplicação inicial do questionário, mudou significativamente na aplicação final, assim como o aumento dos que afirmaram que conhecem os benefícios das plantas aromáticas associadas ao sabão, justificado possivelmente pelas atividades de EA desenvolvidas que

Revbea, São Paulo, v.16, № 1: 450-471, 2021. 
possibilitou aos estudantes perceber benefícios das plantas aromáticas e a diminuição daqueles que nunca procuram saber nada em relação ao assunto, evidenciando a queda na indiferença com relação ao assunto.

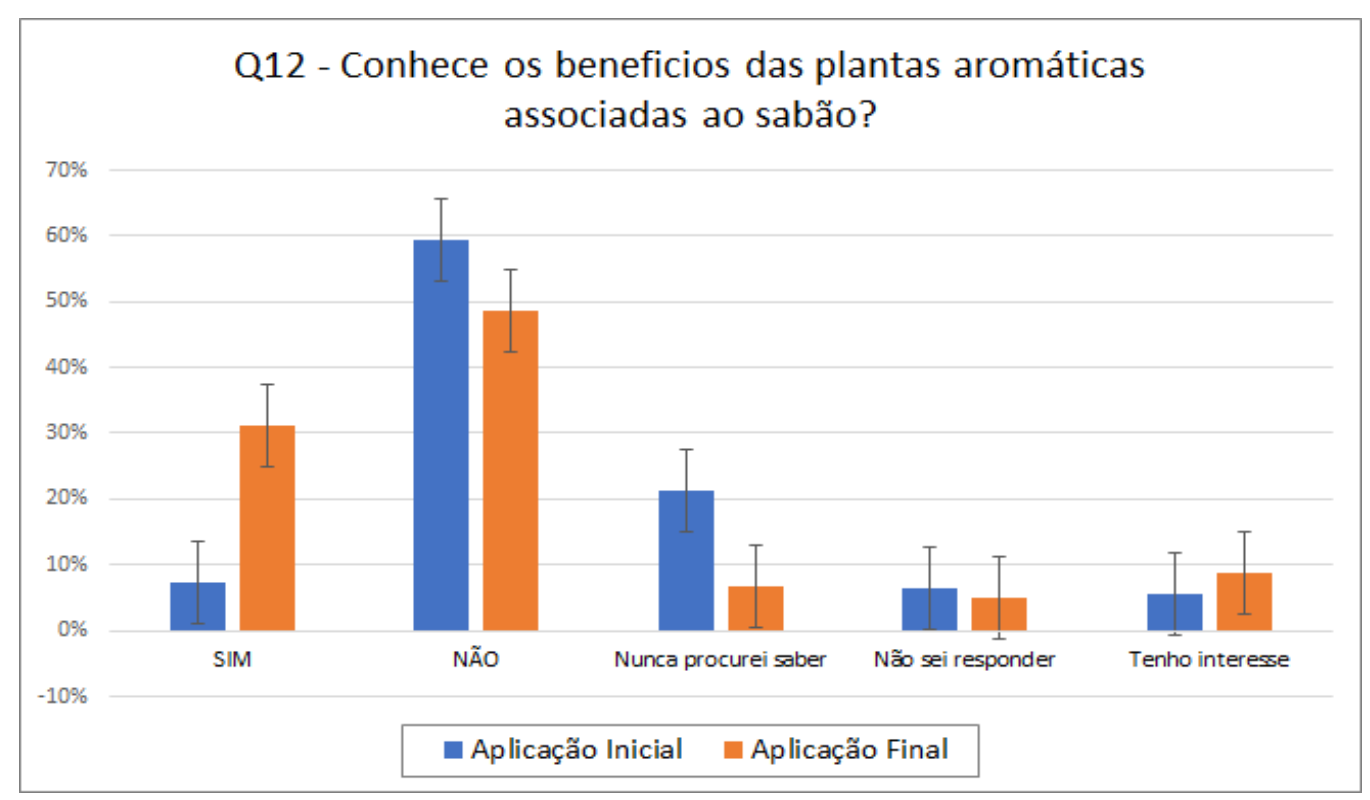

Percebe-se também um aumento no conhecimento sobre as plantas medicinais (questão 12 - Q13), possivelmente justificada pelas palestras e reforçada pelas atividades desenvolvidas no contexto desta pesquisa.

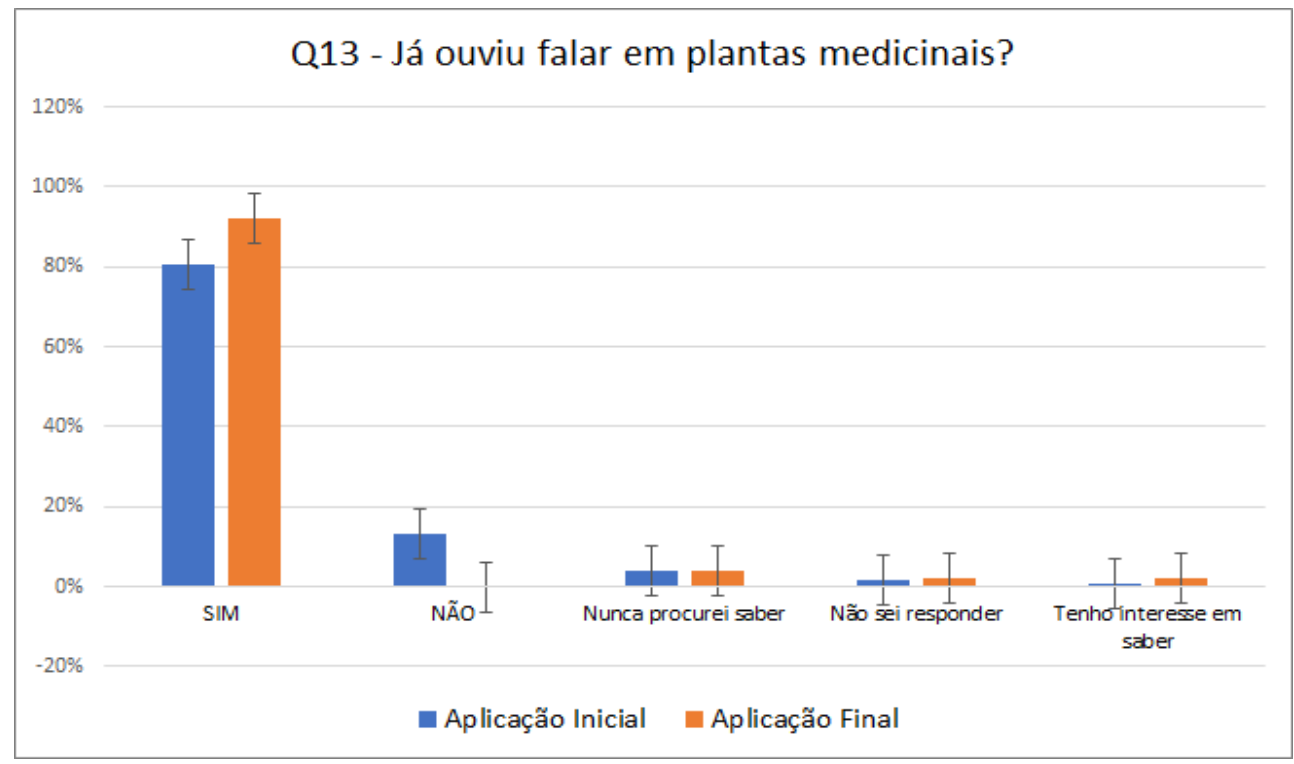

Os dados obtidos indicam a necessidade de se trabalhar continuamente atividades de EA, seja no sentido de sempre buscar o aprimoramento de metodologias como docente, seja no sentido de ser assunto de importância real e urgente como Pinho (2017) relataram em um estudo com alunos de uma escola municipal, em que propuseram a reutilização do óleo de fritura por 
meio da produção de sabão, que mobilizou a comunidade escolar porém, os autores reforçam que a Educação Ambiental vai além da sensibilização da população, sendo necessário uma prática continua da ação.

A utilização da fabricação do sabão artesanal a partir do óleo de cozinha usado não é nenhuma inovação dentro do contexto escolar e esta ação por si só não se caracteriza como uma ferramenta de sensibilização ambiental. No entanto, ao inseri-la dentro do contexto de um conjunto de atividades, respeitando as etapas supracitadas, observam-se suas potencialidades em contribuir para o processo de construção do conhecimento, assim como o estímulo ao engajamento dos estudantes em ações transformadoras (DEMOLY; SANTOS, 2018).

\section{Conclusões}

Do exposto no presente trabalho, pode-se concluir que, a aplicação de oficinas com sabão artesanal que se reutiliza o óleo de cozinha se mostrou eficiente para o engajamento, a sensibilização e a conscientização de alunos do Ensino Médio, pois esta aula prática parte de uma problemática ambiental próxima à realidade dos estudantes. Isso reforça a potencialidade das aulas práticas e oficinas como construtoras de um processo de um ensino e aprendizagem mais relevante. Além disso, os alunos conseguiram reavaliar sua percepção, como membros ativos na conservação do meio ambiente. Durante todo o processo não houve nenhuma intercorrência de difícil resolução, tampouco foi necessário o uso de materiais de alto custo. Logo, podemos concluir que a sequência didática proposta é viável de ser reaplicada em outras instituições de ensino.

\section{Agradecimentos}

Ao Colégio Estadual Padre Sebastião e aos alunos sem os quais este projeto não teria acontecido. À Universidade Federal de Juiz de Fora, por tornar possível o mestrado da autora, e à CAPES, por incentivar, regrar e dispor sobre os cursos de pós-graduação (Mestrado e Doutorado).

\section{Referências}

BAPTISTA, V. F. A relação entre o consumo e a escassez dos recursos naturais: uma abordagem histórica. Saúde \& Ambiente em Revista, v. 5, n. 1, p. 8-14, 2010.

BRASIL, Ministério da Educação. A Base Nacional Comum Curricular Apresentação. Brasília: MEC. 2017. Disponível em: <http://basenacionalcomum.mec.gov.br/>. Acesso em: 02 abr. 2019. 
BRASIL. Ministério da Educação. Resolução oㅡ 2, de 15 de junho de 2012. Estabelece as Diretrizes Curriculares Nacionais para a Educação Ambiental. Brasília: Ministério da Educação, 2012. Disponível em: $<$ http://conferenciainfanto.mec.gov.br/images/conteudo/iv-cnijma/diretrizes.pdf>. Acesso em: 02 dez. 2019.

BRASIL. Ministério do Meio Ambiente. Diretoria de Educação Ambiental. Programa Nacional de Educação Ambiental. Brasília: Ministério do Meio Ambiente, 2005.

BUNGE. Notícias: Soya Expande Programa de Reciclagem de Resíduo do Óleo de Cozinha. São Paulo, Janeiro de 2009. Disponível em: $<$ http://www.bunge.com.br/Imprensa/Noticia.aspx?id=149> Acesso em: 6 ago. 2019.

BZUNECK, J. A.; GUIMARÃES, S. E. R.. A promoção da autonomia como estratégia motivacional na escola. In: BORUCHOVITCH, E.; BZUNECK, J. A.; GUIMARÃES S. E. R. (Orgs.), Motivação para aprender: aplicações no contexto educativo. Vozes. Petrópolis-RJ: p. 41-70. 2010.

CARVALHO, A. N. P. (cord.) Termodinâmica: um ensino por investigação. São Paulo: Feusp, 1999.

COLESANTI, M. Paisagem e Educação Ambiental. In: Encontro Interdisciplinar sobre o Estudo da paisagem. Rio Claro: UNESP, 1996.

COSTA, D. A.; LOPES, G. R.; LOPES, J. R. Reutilização do óleo de fritura como uma alternativa de amenizar a poluição do solo. Revista do Centro de Ciências Naturais e Exatas. Santa Maria. v. 14, p. 243-253, 2015.

COSTA, F. J. C.; DOS SANTOS, M. W. G.; LOPES, A. R. Uma Aplicação Mobile para Mediação de Aulas de Educação Ambiental e Biologia. Anais do IV Congresso sobre Tecnologias na Educação. SBC, p. 537-543. 2019.

DA CRUZ, A. A. P. et al. A logística reversa do óleo de cozinha como ferramenta de sustentabilidade. Anais Sintagro, v. 11, n. 1, 2019.

DEMOLY, K. R. A.; SANTOS, J. S. B. Aprendizagem, Educação Ambiental e Escola: Modos de En-Agir na Experiência de Estudantes e Professores. Rev. Ambiente \& Sociedade, v. 21. São Paulo, 2018.

DE LUCENA, K. P.; DE ALBUQUERQUE, W. G.; MOURA, E. F. Alternativas ambientais: reciclagem do óleo de cozinha na fabricação de sabão. Revista INTESA, v. 8, n. 2, p. 08-14, dez., 2014.

DEMOLY, K. R. A.; SANTOS, J. S. B. Aprendizagem, Educação Ambiental e Escola: Modos de En-Agir na Experiência de Estudantes e Professores. Rev. Ambiente \& Sociedade, v. 21. São Paulo, 2018. 
FILHO, S, T. SANTOS, A. As. da S.. ALMEIDA, T. M. de. S., E.. Tecnologia ambiental aplicada ao gerenciamento e processamento do óleo vegetal residual no estado do Rio de Janeiro. Revista Eletrônica em Gestão, Educação e Tecnologia Ambiental - REGET/UFSM, Santa Maria - RS, v. 15 n. 15, p. 3026- 3035, out. 2013.

GODOY, A. S. Refletindo sobre critérios de qualidade da pesquisa qualitativa. Gestão.Org, v. 3, n. 2, mai./ago. 2005.

IBGE - Instituto Brasileiro de Geografia e Estatística. Cidades e estados. Local de publicação. 2018. Disponível em: <https://www.ibge.gov.br/cidades-eestados/ri/valenca.html>. Acesso em 8 out. 2020.

KRÜGER, Eduardo L. Uma abordagem sistêmica da atual crise ambiental. Desenvolvimento e Meio Ambiente, n. 4, p. 37-43, jul./dez. Editora da UFPR, 2001.

LEFF, E. Saber ambiental: sustentabilidade, racionalidade, complexidade e poder. 2. ed. Petrópolis: Vozes, 2001.

LIMA, D. L. A importância da sequência didática como metodologia no ensino da disciplina de física moderna no ensino médio. Revista triângulo, v. 11, n. 1, p. 151-162, 2018.

LOUREIRO, C. F. B.. Educação Ambiental crítica: contribuições e desafios. In: MELLO, S.; TRAJBER, R.. (Org.). Vamos cuidar do Brasil: conceitos e práticas em Educação Ambiental. 1ed. Brasília: MEC/UNESCO, 2007, v. 1, p. 65-73.

MARCONI, M. de A.; LAKATOS, E. M.. Metodologia do trabalho científico: procedimentos básicos, pesquisa bibliográfica, projeto e relatório. Publicações e trabalhos científicos, v. 7, p. 225, 2001.

MENEZES, I. M. S. Escola e Meio ambiente: Análise das Ações do Projeto em Educação Ambiental Desenvolvidas na Escola Estadual Integral do Ensino Médio Ginásio Pernambuco do Recife-PE-Brasil. Tese. Repositório de Tesis y Trabajos Finales UAA, 2019.

NOVICKI, V.; DE SOUZA, D. B. Políticas Públicas de Educação Ambiental e a atuação dos Conselhos de Meio Ambiente no Brasil: perspectivas e desafios. Ensaio: avaliação e políticas públicas em Educação, v. 18, n. 69, p. 711-736, 2010.

PINHO, M. J. S.; SANTOS, J. L. Reciclagem de óleos residuais de estabelecimentos gastronômicos na cidade de Jaguarari (BA) por meio da Educação Ambiental. Revista Brasileira de Educação Ambiental (RevBEA), v. 12, n. 2, p. 102-113, 2017.

REIS, M. F. P.; ELLWANGER, R. M.; FLECK, E. Destinação de óleos de fritura. Anais do 24ํㅡㄹ Congresso Brasileiro de Engenharia Sanitária e Ambiental. ABES - Associação Brasileira de Engenharia Sanitária e Ambiental. Belo Horizonte. 2007. 
SABESP. Pesquisa Sabesp: Reciclagem de óleo. 2011. Disponível em: $<$ http://site.sabesp.com.br/site/interna/Default.aspx?secaold=82>. Acesso em 05 ago. 2020.

SANTOS, W. S.; DOS SANTOS G., E. A.; CARVALHO, J. N. As Contribuições do Estudo Extra Classe nas Notas Escolares dos Alunos de uma Escola da Cidade de Barra do Bugres - Mato Grosso. Ciência e Natura, v. 39, n. 1, p. 127-132, 2017.

SILVA, M. de O. Palestras para a Educação Ambiental com proposta de tipo ideal na Serra do Periperi em Vitória da Conquista, Bahia, nordeste do Brasil. Educação Ambiental em Ação, n. 71, 2020.

SCHWANTZ, P. I. et al. Reciclagem de Resíduos Oleosos: Ação De Sensibilização Ambiental Com Alternativas de Reciclagem pela Produção Artesanal de Sabão. Revista Estudo \& Debate, v. 26, n. 1, p. 39-55, 2019.

SILVA, L. F.; CARVALHO, L. M. A temática ambiental e as diferentes compreensões dos professores de física em formação inicial. Ciência \& Educação. v. 18, n. 2, p. 369-383, 2012.

TALAMONI, A. C. B.; PERES, W. C.; PINHEIRO, H. M. S. \& PINHEIRO, M. A. A. Histórico da Educação Ambiental e sua relevância à preservação dos manguezais brasileiros. Cap. 2: p. 57-73. In: PINHEIRO, M. A. A.; TALAMONI, A. C. B. (Org.). Educação Ambiental sobre Manguezais. São Vicente: UNESP, Instituto de Biociências, Campus do Litoral Paulista, 165 p. 2018.

TOZONI-REIS, M. F. C. Educação Ambiental: natureza, razão e história. 2. ed., Autores Associado, Campinas, 174 pp, 2008.

VIRGENS, R. de A. A Educação Ambiental no ambiente escolar. xi, 17 f., il. Consórcio Setentrional de Educação a Distância, Universidade de Brasília, Universidade Estadual de Goiás, Brasília, 2011.

VIZÚ, J. A.; MACHADO, G. C.; SILVA, B. C.; MACHADO, J. C. V.; SILVA, M. A.; MARQUES, M. J. Reciclagem de óleo utilizado em frituras através da fabricação de sabão elaborado com óleo essencial de Piper calossum extraído por arraste a vapor. Cadernos de Agroecologia. v. 13, n 1, p. 1-05, jul, 2018. 